\title{
Economic Tools for Merger Appraisal: A Theoretical and Empirical Standpoint
}

\author{
Panagiotis N. Fotis*
}

Hellenic Competition Commission, General Directorate of Competition, Greece

\begin{abstract}
This paper presents in a retrospective manner economic tools for merger control and market delineation. Particularly, it focuses, via theoretical and empirical standpoint, on price based techniques for merger control such as tools of market delineation in one sided markets as the "Could Approach» of Critical Loss analysis, and tools for measuring the unilateral effects of a merger such as the Upward Pricing Pressure by Farrell \& Shapiro (2010), the Gross Upward Price Pressure Index (2010) by Moresi (2010) and the Buying Power Index by Blair \& Harrison (2010). The theoretical standpoint reveals that economic tools for merger control have been enhanced through the time in order to deal with the increasingly amount of merger cases, while the empirical standpoint supports the idea that competition economics have become a standard reference during the analysis of them. Even though competition analysis for antitrust and abuse of dominant position cases is considered to be a castle for lawyers, economists play a crucial role in quantifying the effects of mergers on competition.
\end{abstract}

Keywords: SNIPP test, Critical Loss Analysis, Upward Pricing Pressure, Gross Upward Pricing Pressure Index, Buying Power Index.

\section{INTRODUCTION}

Traditionally merger control is an area of competition analysis that has been dominated by economists. Even though competition analysis for antitrust and abuse of dominant position cases is considered to be a castle for lawyers, economists play a crucial role in quantifying the effects of mergers on competition.

The purpose of this paper is to present from an economic point of view and in a retrospective manner the economic tools for merger control and market delineation. That is, it does not try to assess how do the courts assess their evaluation on merger cases, but it particularly focuses, via theoretical and empirical standpoint, on price based techniques for merger control such as tools of product market delineation ${ }^{1}$ in one sided markets ${ }^{2}$ as the «Could Approach» of Critical Loss analysis («CL»), and economic tools for measuring the unilateral effects of a merger such as the Upward Pricing Pressure («UPP») by Farrell \& Shapiro (2010), the Gross Upward Price Pressure

*Address correspondence to this author at the P. loakim 5, 12132, Peristeri, Athens, Greece; Tel: 0030 6947609741; E-mail: p1972fo@gmail.com

${ }^{1}$ SSNIP test and CL analysis may be used for the definition of the geographical market as well. See, inter alia, Federal Trade Commission v Occidental Petroleum Corp., 1996-I Trade vs. (CCH) 67,071 (D.D.C. 1986) and Strand (2006).

${ }^{2}$ For the use of SSNIP \& CL methodologies in two - sided markets see Filistrucchi (2008), pp. 16-21.

E-ISSN: 1929-7092/14
Index («GUPPI») by Moresi $(2010)^{3}$ and the Buying Power Index («BPI») by Blair \& Harrison (2010).

Therefore, the novelty of this paper lies in the fact that a variety of theoretical and empirical issues related to priced based techniques for merger control and market delineation are examined and this examination is conducted in a retrospective manner. To the best of my knowledge this paper differs from other papers since it tries to gather and analytically explain the main quantitative tools regarding market delineation which will be very helpful for researchers and academics with an economic background and competition lawyers as well.

The remainder of the paper is organized in the following way. Section 2 theoretically reviews the literature of price - based techniques of Critical Loss analysis, while section 3 presents Upward Pricing Pressure («UPP»), Gross Upward Pricing Pressure («GUPPI») and Buying Power Index («BPI»). Section 4 offers an empirical literature review of the said methods of merger control and section 5 concludes.

\section{A THEORETICAL STANDPOINT OF CRITICAL LOSS ANALYSIS IN MARKET DELINEATION PROCESS}

The Hypothetical Monopoly Test («HMT») is a broader concept than the Small, but Significant

${ }^{3}$ Price based techniques has also been used in order to investigate the coordinated effects of mergers. See, inter alia, Kovacic et al. (2009), Moresi et al. (2011) and the Coordinated Price Pressure Index («CPPI») and Fabra \& Motta (2013).

@ 2014 Lifescience Global 
Nontransitory Increase in Price ( SSNIP») test, ${ }^{4}$ the $\mathrm{CL}$ analysis and other price based techniques that are used in market definition process.

The scope of this section is to present the role of prices and their use in market definition analysis which in turn implies that I will assume that prices are the dominant form of strategic interaction among firms. ${ }^{5}$ For this scope I theoretically review the $\mathrm{CL}$ analysis or the "break even SSNIP tests" in one -sided markets.

\subsection{The "Could Approach» of Critical Loss Analysis}

In this sub section I review the "could approach" or the EU approach of $\mathrm{CL}$ analysis by using the mathematical formulas presented by Harris and Simons (1989), Katz and Shapiro (2003), O' Brien and Wickelgren (2003), Daljord, Sørgard and Thomassen (2008) and Daljord and Sørgard (2011). ${ }^{6}$ The rationale for this is that the formula of the said approach are identical either we assume linear or iso-elastic demand functions. In the literature the profit - maximizing approach, aka the "would - approach» or the US approach, has also been used for market definition purposes ${ }^{7}$.

Especially, following Harris and Simons (1989), the critical loss for a percent price increase is the percentage reduction in quantity required for the price increase to leave profits unchanged. Alternatively, as tabulated by Daljord and Sørgard (2011) the critical loss is calculated as the

[L]argest relative reduction in demand the hypothetical monopolist of all products in the candidate market can profitably sustain following an increase in the price of all firms in the candidate market by a given percent.

If the reduction in unit sales is greater than the critical loss, then the price increase will reduce profits.

\footnotetext{
${ }^{4}$ For an application of merger simulation analysis in merger cases see, inter alia, CM5885, Centrica Plc/Dynegy Storage Ltd and Dynegy Onshore Processing, August 2003, Case COMP/M. 3216, Oracle/PeopleSoft, [2005] L218/6, Case COMP/M.1672, Volvo/Scania, [2001] O.J. L143/74, Case COMP/M.3083, GE/Instrumentarium, [2004] O.J. L109/1. See also Ivaldi \& Lorincz (2011) for a latest review of SSNIP test methodology.

${ }^{5}$ In some markets, quality, advertising and other forms of non price competition are the dominant forms of strategic interaction among firms. The incorporation of these strategic variables into the analysis here is out of the scope of this paper.

${ }^{6}$ The reader who is interested in criticisms of $\mathrm{CL}$ analysis may see, inter alia, the papers of Moresi, Salop and Woodbury (2008), Farrell and Shapiro (2008), Daljord et al. (2008), Katz and Shapiro (2003), O'Brien and Wickelgren (2003), Werden (2002), Danger and Frech (2001), Lagenfeld and Li (2001), for more details.

${ }^{7}$ For the US approach of CL analysis see, inter alia, Werden $(1998,2002)$.
}

However, if the reduction in unit sales is less than the critical loss, the price increase will increase profits. ${ }^{8}$

Calculating the critical loss requires balancing two effects: a) a given price increase raises the profit margin earned on all units that are sold, but b) it also reduces the quantity demanded resulting in fewer units being sold. The critical loss is the percentage reduction in quantity such that these two effects just balance.

The benefit of a hypothetical monopolist from a price increase is the amount of the price increase times the quantity that will be sold at the new price. Correspondingly, the cost is equal to the pre-merger margin times the quantity reduction caused by the price increase.

If we denote $\frac{\Delta p}{p}$ the percentage price increase and $m u=\frac{p-c}{p}$ the margin measured as a percentage of pre merger prices, where the pre merger variable cost is $c$, then the critical loss is

$$
C L=\frac{\frac{\Delta p}{p}}{\frac{\Delta p}{p}+m u}
$$

Eq. (1) implies that for a given percentage price increase, the critical loss is smaller the larger is the margin. Intuitively, the larger is the margin, the greater the profit lost from a given reduction in quantity, so the smaller the reduction in quantity required for a given price increase to be unprofitable.

A percentage price increase of a hypothetical monopolist will be profitable if eq. (2) is satisfied,

$$
\frac{\Delta p}{p} A \eta^{o w n}<\frac{\frac{\Delta p}{p}}{\frac{\Delta p}{p}+m u}
$$

where $A \eta^{o w n}$ is the actual own price elasticity, that is, the corresponding estimated coefficient from the demand function under scrutiny and $\frac{\Delta p}{p} A \eta^{o w n}=A L$ is the actual loss of the hypothetical monopolist from the price increase.

\footnotetext{
${ }^{8}$ The authors assume a relative price increase of all sales of one product.
} 
Solving for $A \eta^{\text {own }}$ from eq. (2) we derive eq. (3),

$$
A \eta^{\text {own }}<\frac{\frac{\frac{\Delta p}{p}}{\frac{\Delta p}{p}+m u}}{\frac{\Delta p}{p}}
$$

where $C \eta^{\text {own }}=\frac{C L}{\frac{\Delta p}{p}}$ is the critical own price elasticity.

Therefore, a distinct relevant product market satisfies the following rule:

$$
A \eta^{o w n}<C \eta^{\text {own }}
$$

Katz and Shapiro (2003) assumed a hypothetical monopolist with two products, A \& B. Assuming an increase in product A's price and given the fraction of sales that is diverted to product $B$ following the price increase of product $A$, that is, the Diversion Ratio ( $\mathrm{DR}$ ») of products $A \& B,{ }^{9}$ then the Actual loss of a hypothetical monopolist is

$A L=\frac{\frac{\Delta p}{p}(1-D R)}{m u}$

A percentage price increase of product $A$ by a hypothetical monopolist will be profitable if eq. (6) is satisfied,

$$
A L<C L \text { if and only if } D R>C L
$$

Following O'Brien and Wickelgren (2003), we can assess the consistency of $\mathrm{CL}$ analysis if we calculate the actual loss in unit sales from a given price increase. ${ }^{10}$ The mathematical formula for actual loss from a given price increase is given in eq. (7),

$$
A L=\frac{\Delta p}{p}\left[\frac{1}{m u}-\eta^{\text {cross }}\right]
$$

${ }^{9}$ The DR from product $A$ to product $B$ is the fraction of the reduction in sales of product $A$ that is diverted to product $B$ following a price increase on product $A$.

That is, $D R_{A, B}=\frac{\partial p_{B}}{\partial p_{A}} / \frac{\partial p_{A}}{\partial p_{A}}=\frac{\eta^{\operatorname{cross}(A, B)}}{\eta^{\text {own }(A, A)}}$. In case where own and gross price elasticities of demand cannot be estimated, the DR is calculated in the following way: $D R_{A, B}=\frac{S_{B}}{\sum S_{i}-S_{A}}$, where $\mathrm{S}$ is the market share of the i products in the market.

${ }^{10}$ The authors assume that a hypothetical monopolist controls two products and derive the formula of a profitable uniform price increase of the two products. The formula is called the "Break Even SSNIP Test". where $\eta^{\text {cross }}$ is the cross elasticity of demand for product $B$ with respect to the price of product $A$. A percentage price increase for products $A$ and $B$ will be profitable if the actual loss does not exceed the critical loss, that is,

$\frac{\Delta p}{p}\left[\frac{1}{m u}-\eta^{\text {cross }}\right]<\frac{\frac{\Delta p}{p}}{\frac{\Delta p}{p}+m u}$

If

$\frac{\frac{\Delta p}{p}}{\frac{\frac{\Delta p}{p}+m u}{m u}}=\frac{C L}{m u}>\eta^{\text {cross }}$

then the actual loss exceeds the critical loss and products A \& B do not constitute a single product market.

Therefore, a percentage price increase for products $A$ and $B$ will be profitable if actual loss is lower than critical loss or eq. (10) is satisfied. ${ }^{11}$

$\eta^{\text {cross }}>\frac{C L}{m u}$

Eq. (10) implies that holding cross elasticities between the merging firms constant, a given price increase is more likely to be profitable the larger is the margin. This result implies that mergers are more anticompetitive in more concentrated relevant product markets.

Daljord et al. (2008) criticize the CL formula presented by Katz \& Shapiro. Following the authors, product $A^{12}$ will constitute a distinct relevant product market whether eq. (11 or 12) are satisfied,

$\left(\frac{\Delta p_{A}}{p_{A}}\right) A \eta^{o w n}<\frac{\frac{\Delta p_{A}}{p_{A}}}{\frac{\Delta p_{A}}{p_{A}}+m u_{A}}\left(1+\lambda D R_{A, B}\right)$

or

$A \eta^{o w n}<C \eta^{o w n}\left(1+\lambda D R_{A, B}\right)$

\footnotetext{
${ }^{11}$ Respectively, eq. (10) may also be written as $D R \geq C L$.

${ }^{12}$ The authors assume that a hypothetical monopolist increases only the price of product $A$, which is a «small product» in terms of sales. This is called the "single product" criterion.
} 
where $m u_{A}=\frac{p_{A}-c_{A}}{p_{A}}$ is the product A's margin measured as a percentage of pre merger prices \& variable cost and $\lambda=\frac{p_{B}-c_{B}}{p_{A}-c_{A}}$ is the relative profitability of products A \& B. Given that $\eta^{o w n}=\frac{1}{m u}$, eq. (11) becomes,

$$
\frac{\frac{\Delta p_{A}}{p_{A}}}{m u}=A L<\lambda D R_{A, B}
$$

If $\lambda=1$ as in Katz and Shapiro, then eq. (13) is satisfied if and only if $D R \geq A L$.

Lastly, Daljord and Sørgard (2011) consider large product's asymmetries in terms of sales in the market. The authors consider a hypothetical monopolist who imposes a uniform price increase of both products, A the "small product" and B - the "large product". Assuming that $D R$ of both products are proportional to sales, ${ }^{13}$ product $A$ will constitute a distinct relevant product market if eq. (14) is satisfied. ${ }^{14,15}$

$$
\frac{\frac{\Delta p}{p}}{2\left(\frac{\Delta p}{p}+m u\right) S_{A}}=A L \leq D R
$$

The authors state that eq. (13) leads to narrower relevant product market than eq. (14) if

$$
S_{A}<\frac{m u}{2\left(\frac{\Delta p}{p}+m u\right)}
$$

\section{UPP, GUPPI \& BPI APPROACHES}

The UPP methodology assumes static price setting competition with differentiated products (i.e. firms in the market exhibit excess capacity). ${ }^{16}$ Consider two firms 1

\footnotetext{
${ }^{13}$ That is, $D R=\frac{D R * S_{A}}{\left(1-S_{A}\right)}$.

${ }^{14}$ For symmetric firms (identical price and marginal costs, i.e., margins), the equivalent formula of eq. (13) is $S_{i} D R_{i, j}+\left(1-S_{i}\right) D R_{j, i} \geq \frac{\frac{\Delta p}{p}}{\frac{\Delta p}{p}+m u}$.

${ }^{15}$ If we assume no asymmetries in Daljord et al. (2008), then eq. (13) leads to a broader product market than eq. (13).

${ }^{16}$ In addition the UPP methodology does not take into account the effects of potential side responses (i.e., inert alia, entry). See for an equivalent methodology O'Brien and Salop (2000). The UPP methodology can also be
}

\& 2 that produce $A \& B$ respectively. Suppose a merger of firms $1 \& 2$. Farrell and Shapiro (2010) state that a UPP on product sold by firm 1 will be created after the merger, ${ }^{17}$ if

$U P P_{A}: D R_{A B} * M U_{B}>V C E_{A}$

where $D R_{A B}$ is the $\mathrm{DR}$ from product $\mathrm{A}$ to product $\mathrm{B}$, $M U_{B}=P_{B} m u_{B}=P_{B} \frac{P_{B}-C_{B}}{P_{B}}=P_{B}-C_{B}$ is the price cost margin (currency per unit) of product $B$ at pre-merger values, $m u_{B}$ is the price - cost margin of product $\mathrm{B}$ and $V C E_{A}$ is the variable cost efficiencies post merger for product $A$ at pre-merger values.

Therefore, firm 1 has an incentive to increase the price of product $A$ after the clearness of the merger if the net profit effect of such an increase is higher than the efficiencies emerged by the merger. ${ }^{18}$

Farrell and Shapiro state that UPP may be used as an indicator of the merger's likely unilateral effects. They propose that mergers generating positive net UPP, warrant, at least, further scrutiny.

The GUPPI methodology in euro terms expresses the incentive of firm 1 to increase the price of its product $(A)$ with respect to product B. As tabulated by Salop and Moresi (2009:19) the said increase follows 'a result of substitution between that product and the product sold by its merger partner firm 2'. If we assume that $P_{A}=P_{B}$ the GUPPI formula is given in eq. (17). ${ }^{20}$

$$
G U P P I_{A}=D R_{A B}^{*} M U_{B}
$$

The higher the diversion ration of firm 1 or the price cost margin of the merger partner or both of them, the higher the GUPPI of product $A$ after the merger. Eq. (18) expresses the GUPPI using the percentage margin rather than the euro margin, ${ }^{21}$

$$
G U P P I_{A}=D R_{A B}^{*} m u_{B}
$$

\footnotetext{
used in quantity setting competition and bidding (auctions) competition. See Moresi (2009) and Moresi (2010), p 3.

${ }^{17}$ Assuming that product B's price does not change after the merger and there are no productive efficiencies.

${ }^{18}$ The same test must be performed for product $B$. That is, $U P P_{B}: D R_{B A} * M U_{A}>V C E_{B}$

${ }^{19}$ See Farrell and Shapiro (2010), p. 3. Schmalensee (2009) has also proposed the following formula for UPP: $U P P_{A}^{*}=D R_{A B} * M U_{B}-V C E_{A}+D R_{A B} V C E_{B}$. See also Werden (1996).

${ }^{20}$ The equivalent formula for firm 2's product (B) is $G U P P I_{B}=D R_{B A} * M U_{A}$.

${ }^{21}$ The equivalent formula for firm 2's product (B) is $G U P P I_{B}=D R_{B A} * m u_{A}$.
} 
If we assume that $P_{A} \neq P_{B}$ (Moresi 2010), the GUPPI formulas in euro and percentage terms are given by equations $\left(17^{\prime}\right)^{22} \&\left(18^{\prime}\right)^{23}$ correspondingly:

$G U P P I_{A}=D R_{A B} * M U_{B} * \frac{P_{B}}{P_{A}}$

$G U P P I_{A}=D R_{A B} * m u_{B} * \frac{P_{B}}{P_{A}}$

where $\frac{P_{B}}{P_{A}}$ is the relative price of product $\mathrm{B}$ in terms of product A. As tabulated by Moresi (2010:7) «the products of the two merging firms would comprise a relevant antitrust market if»,

$\operatorname{GUPPI}_{A, B}>2 S S N I P$

where SSNIP is the profit - maximizing SSNIP test. ${ }^{24}$

The Buying Power 'is the power to reduce price below the competitive levels by restricting purchases' ${ }^{25}$ The existence of a large buyer on the buying side, assuming no price discrimination, may affect the total supply in the downstream market by reducing the quantities sold from the firms in the upstream market and input prices as well as may harm downstream consumers by increasing final prices. ${ }^{26}$

The measurement of the Buying Power of the merged entity depends on the structure of the downstream market. In a competitive downstream market each buyer purchases the quantity supplied from the upstream firms until the value of the marginal product equals the price of the product under scrutiny. In a 'pure monopsony' downstream market, the buyer will restrict its purchases at the point where the value of the marginal product equals its marginal cost. That is,

\footnotetext{
${ }^{22}$ The equivalent formula for firm 2's product (B) is $G U P P I_{B}=D R_{B A} * M U_{A} * \frac{P_{A}}{P_{B}}$.

${ }^{23}$ The equivalent formula for firm 2's product (B) is $\operatorname{GUPPI}_{B}=D R_{B A} * m u_{A} * \frac{P_{A}}{P_{B}}$.

${ }^{24}$ Following Werden (2002) the said formula may be expressed as $D R \geq \frac{\frac{\Delta p}{p}}{\left(2 \frac{\Delta p}{p}+m u\right)}$.

${ }^{25}$ In this paper I am interested in the existence of market power on the buying side of the market where a large buyer may be present in several geographical areas. See Blair and Harrison (2010), p. 53 and OECD (2008), p. 9.

${ }^{26}$ Restrictions of the degree of competition in vertical markets may also be found in Zevgolis and Fotis (2012).
}

$B P I=\frac{1}{\varepsilon}$

where $\varepsilon$ is the market elasticity of supply. ${ }^{27}$ The higher the $\varepsilon$, the lower the buyer's buying power. That is, the higher the ability of the firms in the upstream market to monitor the supply in response to price changes, the lower the ability of the buyer to possess monopsony power.

When the downstream market consists of a large buyer and a fringe of competitive firms the BPI is given in eq. (21),

$$
B P I=\frac{S}{\varepsilon+\eta^{C F}(1-S)}
$$

where $S$ is the market share of the large buyer and $\eta^{C F}$ is the own demand price elasticity of the competitive fringe.

Sensitivity analysis of eq. (21) indicates that a) $\frac{\partial B P I}{\partial S}>0$ and b) $\frac{\partial B P I}{\partial \varepsilon}=\frac{\partial B P I}{\partial \eta^{C F}}<0$. That is, the higher the market share of the large buyer the higher the deviation from the competitive outcome. However, the higher the market elasticity of supply and the own price elasticity of demand of the competitive fringe, the lower the buying power of the large buyer.

Additionally, as the quantity supplied becomes more responsive to changes in prices, the ability of the large buyer to exercise its buying power declines and firms in the upstream market redirect its employment to other products where prices may be higher. On the other hand, as the demand elasticity of the competitive fringe becomes more elastic, the deviation from the competitive level declines since any decline of the large buyer's purchases are captured by the enhanced purchases of the competitive fringe.

\section{AN EMPIRICAL STANDPOINT}

The scope of this section is to empirically review the literature concerning the application of priced based techniques for merger control. In particular, the techniques in question have been used in many merger cases much like in the European Union and the U.S.A. Table 1 presents selected merger cases where the said techniques were used by the competition authorities.

\footnotetext{
${ }^{27}$ See Blair and Harrison (2010), p. 54-55 and the footnotes therein.
} 
Table 1: Application of Critical Loss Analysis: Merger Cases from EU and USA

\begin{tabular}{|c|c|c|c|}
\hline \multirow{9}{*}{ 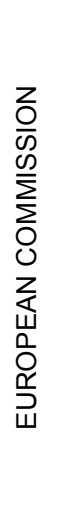 } & Arjowiggins / M-real Zanders Reflex ${ }^{1}$ & & FTC v Occidental Petroleum Corp ${ }^{11}$ \\
\hline & Ineos / Kerling ${ }^{2}$ & \multirow{8}{*}{ 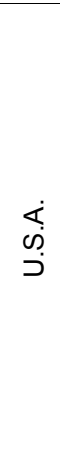 } & FTC v TenetHealthcare Corp. ${ }^{12}$ \\
\hline & $\mathrm{ABF} / \mathrm{GBI}{ }^{3}$ & & US v SunGard and Comdisco ${ }^{13}$ \\
\hline & Alo / $\mathrm{MX}^{4}$ & & FTC v Swedish Match North America Inc..$^{14}$ \\
\hline & KLM / Martinair ${ }^{5}$ & & Plaintiff, v. Whole Foods \\
\hline & Arsenal / DSP 6 & & Market, Inc. and Wild Oats Markets, Inc. ${ }^{15}$ \\
\hline & Lufthansa / SN Airholding ${ }^{7}$ & & \\
\hline & Dunfermline Press / Berkshire Trinity ${ }^{8}$ & & \\
\hline & $\begin{array}{l}\text { Mirror Homebase / Focus } \\
\text { Lovefilm / Amazon }^{10}\end{array}$ & & \\
\hline
\end{tabular}

Notes: ${ }^{1}$ Case COMP/M. 4513 Arjowiggins/M-real Zanders Reflex, ${ }^{2}$ Case COMP/M. 4734 Ineos/Kerling, ${ }^{3}$ Case COMP/M. 4980 ABF/GBI, ${ }^{4}$ Case COMP/M. 4989 Alo/MX, ${ }^{5}$ Case COMP/M. 5141 KLM/Martinair, ${ }^{6}$ Case COMP/M. 5153 Arsenal/DSP, ${ }^{7}$ Case COMP/M. 5335 Lufthansa/SN Airholding, ${ }^{8}$ No. ME/3315/07 (http://www.oft.gov.uk/OFTwork/mergers/decisions/2008/dunfermline2), ${ }^{9}$ No. ME/3427/07 (http://www.oft.gov.uk/OFTwork/mergers/Mergers_home/decisions/ 2008/Home), ${ }^{10}$ No. ME/3534/08 (http://www.oft.gov.uk/OFTwork/mergers/Mergers home/decisions/2008/LOVEFiLM), ${ }^{11}$ Federal Trade Commission v Occidental Petroleum Corp., 1996-I Trade vs. (CCH) 67,071 (D.D.C. 1986), ${ }^{12}$ Federal Trade Commission v Tenet Healthcare Corporation, 186 F. $3 d$ 1045 (Eight Circuit 1999 ), ${ }^{13}$ US v SunGard and Comdisco, 172 F. Supp. 2d 172, 182,186-92 and n.21 (D.D.C. 2001), ${ }^{14}$ Federal Trade Commission v Swedish Match North America Inc., 131 F. Supp. 2d 151, 160-62 (D.D.C. 2000), ${ }^{15}$ Federal Trade Commission, Plaintiff, v. Whole Foods Market, Inc., and Wild Oats Markets, Inc. (United States District Court for the District of Columbia), Civ. No. 07-cv-01021-PLF, FTC File No. 0710114.

Source: Author's elaboration of data.

The horizontal acquisition between the Ineos Group Limited and the Norwegian company Kerling ASA in the market of Standard PVC (hereinafter "S - PVC») provides a standard example of application of price based techniques in merger control. The said acquisition was declared to be compatible with the common market and the functioning of the EEA Agreement on $2008 .^{28}$

One of the issues of controversy in this case was that if UK S - PVC market was part of a European market or could be delineated in National grounds. The Chief Economist Team («CET») of DG Comp used CL analysis in order to estimate market elasticity of supply with respect to domestic prices. Imports were claimed by the parties in the merger to be the competitive constraint of the domestic producers.

The critical loss estimates «ranged from 61 to 108 $\mathrm{Kt}$ and from 107 to $170 \mathrm{Kt}$, respectively for $5 \%$ and $10 \%$ price increases». ${ }^{29}$ The actual loss was estimated by surveys or other qualitative data (planned uncommitted capacity expansions, demand forecasts or the costs of switching). ${ }^{30}$

Daljord and Sørgard (2011) elaborate CL methodology in a grocery market in Norway. ${ }^{31}$ The

\footnotetext{
${ }^{28}$ See Commission Decision of 30/1/2008.

${ }^{29}$ See Amelio, De la Mano, and de Matos (2008), p. 57

${ }^{30}$ The CET estimated a partial residual demand elasticity of the merging parties using instrumental variable regression. However, the empirical results weren't statistical significant.

${ }^{31}$ See Daljord and Sørgard (2011), pp 8-11.
}

authors evaluate single - product criterion (eq. 12) and uniform price SSNIP test (eq. 13) and conclude that the delineation of the product market depends on «whether we impose a price increase on only one or all the products».

In particular, for a $5 \%$ SSNIP, the estimate of the critical diversion ratio, the left - hand side of eq. (13), is $16,7 \%$, while the corresponding estimate of eq. (12) is $20 \%$. The application of the said estimates in the above mentioned market indicates that single - product criterion leads to narrower product markets than uniform price SSNIP test in 2 out of 28 outlets under scrutiny.

The empirical results of Hellenic Competition Commission's (HCC's) decision ${ }^{32}$ regarding the delineation of the market of production and distribution of white milk in Greece indicate that fresh, high pasteurization \& condensed milk constitute distinct product markets. This conclusion stems from the empirical results of $\mathrm{CL}$ analysis by Harris and Simons (1989), O' Brien and Wickelgren (2003) and Daljord et al. (2008) and for several percentage price increases of fresh, high pasteurization \& condensed milk. The application of the single - product criterion (Daljord et al. 2008) in two pairs of the said products (between fresh - high pasteurization and fresh - condensed milk)

\footnotetext{
${ }^{32}$ See HCC's Decision No 515/VI/2011, Appendix 1, 'Econometric estimations', pp 121-123.
} 
indicates that for various increases in the price of fresh milk ( $5 \%-30 \%)$, eq. (12) is satisfied since $D R \geq A L$.

Application of the UPP methodology is limited in the literature. Cheung (2011) analyses the merger between US Airways and America West that was cleared in 2005 by the Department Of Justice («DOJ»). The author mostly addresses the theoretical issues between UPP analysis and merger simulation. Also, she investigates whether UPP estimates depend on the type of products under scrutiny (complements or substitutes) and she compares the structural estimates of price changes with UPP results. She states that on average $10 \%$ of the elaborated observations of airlines markets, the UPP formula produces wrong estimates. Lastly, she compares the UPP methodology with the traditional Herfindahl-Hirschman Index («HHI») test and she concludes that the $\mathrm{HHI}$ test is a more severe test.

Fotis (2012c) has found evidences of unilateral effects regarding the merger between Delta and Mevgal in the Greek diary sector. Particularly Table 2 reveals that a hypothetical monopolist would have an incentive to increase the price of high pasteurization milk in relation to fresh and condensed milk. This result is due to the highly estimated coefficient of Diversion Ratio (the fraction of the reduction in sales of high pasteurization milk that is diverted to fresh or condensed milk following a price increase on high pasteurization milk) and the highly estimated price cost margin. ${ }^{33}$

Table 2: Gross Upward Pricing Pressure Index for Various Combinations of White Milk

\begin{tabular}{|c|c|c|}
\hline Products & GUPPI (euro) & GUPPI (\%) \\
\hline \hline${\text { fresh }-\mathrm{hp}^{*}}^{*}$ & $\approx 2.5$ cents & $\approx 1 \%$ \\
\hline $\mathrm{hp}^{*}-$ fresh & $\approx 1.5$ euro & $\approx 123 \%$ \\
\hline con $^{* *}-$ fresh & $\approx 18$ cents & $\approx 15 \%$ \\
\hline${\text { fresh }- \text { con }^{* *}}^{* *}$ con $^{* *}$ & $\approx 1.5$ cents & $\approx 1.7 \%$ \\
\hline $\mathrm{hp}^{*}$ con $-\mathrm{hp}^{*}$ & $\approx 1.16$ euro & $\approx 127 \%$ \\
\hline
\end{tabular}

Notes: "high pasteurization milk, "fresh milk, "' condensed milk. Source: Author's estimations.

Regarding to the other types of white milk, the magnitude of estimated GUPPI is lower. The said index

\footnotetext{
${ }^{33}$ Moresi (2010), p. 3.
}

of condensed milk in relation to fresh milk is $15 \%$, while the corresponding index of the same type of milk in relation to high pasteurization milk is $6 \%$.

Besides, the empirical results from the calculation of Upward Pricing Pressure imply that the downward pricing pressure due to the emerged efficiencies must be high enough in order to outweigh the incentive of a hypothetical monopolist to raise the price of the product under scrutiny.

Varma (2009) simulates 10.000 different industries with a hypothetical merger in each industry in order to elaborate usefulness of UPP methodology. The author compares the traditional structural approach of market definition with UPP methodology and concludes «that some mergers that would not create a structural presumption under the approaches to market definition typically used in practice would likely create a presumption under the UPP test with a 10 percent presumptive efficiency credit». ${ }^{34}$

Walters (2007) elaborated diversion ratios in order to calculate the anticompetitive effects of retail chain mergers in UK. ${ }^{35}$ The author stated that the empirical results of diversion ratios were promised in the majority of the merger local markets were estimated and these results, combined with local characteristics of the local markets, may be used in order to elaborate the unilateral effects of mergers.

Mathiesen, Nilsen and Sørgard (2009) also analysed diversion ratios in order to elaborate the unilateral effects of Somerfield's acquisition of Morrison's 115 grocery stores in UK. ${ }^{36}$ The authors concluded that market shares may be poor predictors of the actual competition among asymmetrically differentiated products. They found that the price increase following the above mentioned acquisitions was $40 \%$ lower using the observed diversion ratios than the one based upon market shares.

Fotis (2012c) has calculated the range of estimated $\mathrm{BPI}$ of the merged entity in the merger between delta and Mevgal in the Greek diary sector. The analysis focuses in one of the biggest prefectures in Greece for the year 2010 and the estimated results indicate that the BPI of the merged entity is lower in markets with high elasticity of supply and price demand elasticity of

\footnotetext{
${ }^{34}$ See Varma (2009), p. 31.

${ }^{35}$ See the 2006 Vue/A3 Cinema merger and the 2006 HMV/Ottakar's book store merger.

${ }^{36}$ See Mathiesen (2009), p. 1 \& footnotes therein
} 
the competitive fringe than in inelastic markets. Hereto, if the market elasticity of supply is 0 and the own price elasticity of demand of the competitive fringe is 0.5 then the estimated BPI is between $230 \%$ and $240 \%$. An interesting result indicates that if the demand elasticity of the competitive fringe falls from 1 to 0.5 , while the market elasticity remains stable, the BPI of a large buyer almost doubles.

The European Commission («EC») has assessed the existence of buyer power in many cases. In the case of buying co-operatives ${ }^{37}$ the EC declared that the presence of a large supplier in the upstream market may countervail the increase of the prices in the downstream market. Besides, as tabulated by OECD (2008:258),

[A]n example of a dominant position existing in both the downstream and upstream market was highlighted in the case British Airways, which has been a dominant buyer on the British market for air travel agency services.

In the merger between REWE and $\mathrm{Adeg}^{38}$ the EC stated that the ability of the merged entity to exercise its buying power may be outweighed by the ability of the consumers to buy from the alternative supermarkets and therefore to increase the sales of the rivals. Moreover, in British Airways case ${ }^{39}$ the EC depicted that British Airways had infringed article 82 by making arrangements with travel agents intending to exclude its rivals from the downstream market. However, the said exclusionary effect on British Airways' rivals was upheld by the European Court of Justice. $^{40}$

\section{CONCLUSIONS}

This paper tries to present economic tools for merger appraisal. Particularly, it focuses on price based techniques for merger control in one sided markets, which are used both to delineate the relevant product markets and to measure the unilateral effects of mergers.

In conclusion, the theoretical standpoint reveals that economic tools for merger control have been enhanced

\footnotetext{
${ }^{37}$ See the judgment of the European Court Gøttrup-Klim e.a. Grovvareforeninger v. Dansk Landbrugs Grovvareselskab AmbA [ECR 5641 (1994)].

${ }^{38}$ See Case COMP/M.5047

${ }^{39}$ See IV/D-2/34.780 Virgin/British Airways

${ }^{40}$ Dynamic effects of buying power have also been analysed. See OECD (2008), p. 260. For an application of buying power in merger and antitrust cases see OECD (2008), pp 141-302.
}

through the time in order to deal with the increasingly amount of merger cases, while the empirical standpoint supports the idea that competition economics have become a standard reference during the analysis of them.

The effectiveness of the said techniques depends on the way they used. On the one hand, economists must be very careful when they use them. Particularly, they must realize from the merger case under scrutiny the proper technique that should be applied, particularly when the analysis concerns the delineation of relevant product market. On the other hand, they must "decode» through the analysis of the structure of the product market the nature of the strategic interaction among its "players» in order to apply the correct model that underlies the used technique.

The proper use of economic tools for merger control will be very helpful for competition lawyers as well. Even thought the latter have little to say in this field, it will be extremely auxiliary for them to understand economic theory which in our days plays a crucial role in competition policy.

However, price - based techniques of merger appraisal are useful tools in order to define relevant product markets as well as market power, so as long as they are handled with proper care in markets where other forms of non price competition are the dominant forms of strategic interaction among firms.

\section{REFERENCES}

Amelio, Andrea, Miquel De la Mano, and Manuel Godinho de Matos. 2008. "Ineos/Kerling Merger: An Example of Quantitative Analysis in Support of a Clearance Decision." Retrieved 26 July 2013 (http://ec.europa.eu/competition/publications/ cpn/2008_1_65.pdf)

Blair, Roger D and Jeffrey L Harrison. 2010. Monopsony in Law and Economics. $1^{\text {st }}$ ed. Cambridge University Press.

Cheung, Lydia. 2011. "The Upward Pricing Pressure Test for Merger Analysis: An Empirical Examination." Retrieved 10 May 2013 (http://www.econ.umn.edu/ cheun073/Cheung_JMP.pdf).

Daljord, Øystein. 2009. "An exact arithmetic SSNIP test for asymmetric products." Journal of Competition Law \& Economics 5(3):563-569. http://dx.doi.org/10.1093/joclec/nhp001

Daljord, Øystein, Lars Sørgard and Øyvind Thomassen. 2008. "The SSNIP Test and Market Definition with the Aggregate Diversion Ratio: A Reply to Katz and Shapiro." Journal of Competition Law \& Economics 4(2):263-270. http://dx.doi.org/10.1093/joclec/nhm032

Daljord Øystein and Lars Sørgard. 2011. "Single-Product versus Uniform SSNIPs." International Review of Law \& Economics 32(1):142-146.

Danger, Kenneth $L$ and Harry E Frech. 2001. "Critical Thinking about Critical Loss in Antitrust." The Antitrust Bulletin 40(2):339555. 
Davis, Peter and Eliana Garces. 2010. "Quantitative Techniques for Competition and Antitrust Analysis." $1^{\text {st }}$ ed. Princeton University Press.

Fabra, Natalia and Massimo Motta. 2013. "Coordinated Effects in Merger Cases." Retrieved 1015 January 2014 (www.crcal.org).

Farrell, Joseph and Carl Shapiro. 2008 "Improving Critical Loss Analysis." Antitrust Source 1-17.

Farrell, Joseph and Carl Shapiro. 2010. "Antitrust Evaluation of Horizontal Mergers: An Economic Alternative to Market Definition." The B.E. Journal of Theoretical Economics Policies and Perspectives 10(1):1-39.

Filistrucchi, Lapo. 2008. "A SSNIP Test for Two-Sided Markets: The Case of Media." Retrieved 17 May 2013 (http://papers. ssrn.com/sol3/papers.cfm?abstract_id=1287442).

Fotis, Panagiotis. 2012b. "Competition Policy \& Firm's Damages." Pp. 116-139 in Recent Advances in the Analysis of Competition Policy and Regulation, edited by J. Harrington and Y. Katsoulacos, Edward Elgar.

Fotis, Panagiotis. 2012a. "Competition Policy in Periods of Economic Downturn." International Journal of Economics and Business Research 4(5):560-76. http://dx.doi.org/10.1504/IJEBR.2012.048779

Fotis, Panagiotis. 2012c. "Price - based Techniques for Market Definition \& Buying Power Index." Retrieved 10 October 2013 (http://ssrn.com/abstract=2118502)

Fotis, Panagiotis and Michael Polemis. 2011. "The Use of Economic Tools in Merger Analysis: Lessons from US \& EU Experience." European Competition Journal 7(2):323-47. http://dx.doi.org/10.5235/174410511797248333

Fotis, Panagiotis and Michael Polemis. 2012. "The Short-run Competitive Effects of Merger Enforcement." European Competition Journal 8(1): 183-210. http://dx.doi.org/10.5235/174410512800370025

Froeb, Luke M and Gregory J Werden. 1992. "The Reverse Cellophane Fallacy in Market Delineation." Review of Industrial Organization 7(2):241-274. http://dx.doi.org/10.1007/BF00158143

Harris, Barry C and Joseph J Simons. 1989. "Focusing Market Definition: How Much Substitution is Necessary?." Research in Law and Economics 12(7):207-226.

Ivaldi, Marc and Szabolcs Lorincz. 2011. "Implementing Relevant Market Tests in Antitrust Policy: Application to Computer Servers" Review of Law and Economics 7(1):31-73. http://dx.doi.org/10.2202/1555-5879.1248

Katz, Michael L and Carl Shapiro. 2003. "Critical Loss: Let's Tell the Whole Story." Antitrust Magazine 49-56.

Kovacic, William E, Robert C Marshall, Leslie M Marx and Steven P Schulenberg. 2009. "Quantitative analysis of coordinated effects." Antitrust Law Journal 76(2):397-430.

Lagenfeld, James and Wenqing Li. 2001. "Critical Loss Analysis in Evaluating Mergers." Antitrust Bulletin 299-337.

Mathiesen, Lars, Øivind Anti Nilsen and Lars Sørgard. 2009. "Merger Simulations with Asymmetric firms: The Application of Diversion Ratios." Retrieved 17 February 2013 (http://www.cresse.info/uploadfiles/Mathiesen\%20\&\%20Nilsen\%20\&\%20Sorgard.pdf).

Moresi, Serge. 2009. "Cournot Competition and the UPP Test." Retrieved 25 March 2013 (http://www.ftc.gov/os/comments/ horizontalmergerguides/545095-00036.pdf)

Moresi, Serge. 2010. "The Use of Upward Pricing Pressures Indices in Merger Analysis." Antitrust Source 1-8.

Moresi, Serge, David Reitman, Steven C Salop and Yanis Sarafidis. 2011. "Gauging Parallel Accomodating Conduct Concerns with the CPPI," Retrieved 13 January 2014 (http://crai.com/uploadedFiles/Publications/Gauging_Parallel_Accomodating_Conduct_Concerns_with_the_CPPI(2).pdf).

Moresi, Serge, Steven C Salop and John R Woodbury. 2008. "Implementing the hypothetical monopolist SSNIP test with multi-product firms." Antitrust Source 1-8.

O'Brien Daniel P and Steven C Salop. 2000. "Competitive Effects of Partial Ownership: Financial Interest and Corporate Control." Antitrust Law Journal 67:559-614.

O'Brien Daniel P and Abraham L Wickelgren. 2003. "A Critical Analysis of Critical Loss Analysis." Antitrust Law Journal 71(1):161-184.

OECD. 2008. "Monopsony and Buyer Power Policy Roundtables." Retrieved 11 August 2013 (http://www.oecd.org/daf/ competition/44445750.pdf).

Salop, Steven and Serge Moresi. 2009. "Updating the Merger Guidelines: Comments." Retrieved 25 January 2012 (http://www.ftc.gov/os/comments/horizontalmergerguides/545 095-00032.pdf).

Schmalensee, Richard. 2009. "Should New Merger Guidelines Give UPP Market Definition?." The Antitrust Chronicle 1:1-7.

Strand, Niklas. 2006. "A Simple Critical Loss Test for the Geographical Market." Journal of Competition Law and Economics 2:697-707. http://dx.doi.org/10.1093/joclec/nhl020

Varma, Gopal Das. 2009. "Will Use of the Upward Pricing Pressure Test Lead to an Increase in the Level of Merger Enforcement?." Antitrust 24(1): 27-32.

Walters, Chris. 2007. "Diversion ahead Approximating diversion ratios for retail chain mergers Retrieved 25 October 2012 (http://www.competition-commission.org.uk/assets/competitioncommission/docs/pdf/noninquiry/our_role/analysis/diversion_ratios.pdf).

Werden, Gregory. 1996. "A Robust Test for Consumer Welfare Enhancing Mergers Among Sellers of Differentiated Products." Journal of Industrial Economics 44(4):409-413. http://dx.doi.org/10.2307/2950522

Werden, Gregory. 1998. "Demand Elasticities in Antitrust Analysis." Antitrust Law Journal 66:410-414.

Werden, Gregory. 2002. "Beyond Critical Loss: Tailoring Applications of the Hypothetical Monopolist Paradigm." Retrieved 17 November 2012 (http://papers.ssrn.com).

Zevgolis, Nikolaos and Panagiotis Fotis. 2012. "Prohibition of parallel imports as a vertical restraint: per se approach or a misunderstanding?" European Journal of Law and Economics. http://dx.doi.org/10.1007/s10657-012-9315-6

\section{DOI: http://dx.doi.org/10.6000/1929-7092.2014.03.04}

(c) 2014 Panagiotis N. Fotis; Licensee Lifescience Global.

This is an open access article licensed under the terms of the Creative Commons Attribution Non-Commercial License (http://creativecommons.org/licenses/by-nc/3.0/) which permits unrestricted, non-commercial use, distribution and reproduction in any medium, provided the work is properly cited. 